\title{
Eocene molluscs from the Merlinleigh Sandstone, Carnarvon Basin, Western Australia
}

\author{
Thomas A. Darragh ${ }^{1}$ and George W. Kendrick ${ }^{2,3}$

\begin{abstract}
1 Department of Invertebrate Palaeontology, Museum Victoria, PO Box 666, Melbourne, Victoria 3001, Australia. Email: tdarragh@museum.vic.gov.au

2 Department of Earth and Planetary Sciences, Western Australian Museum, Locked Bag 49, Welshpool DC, Western Australia 6986, Australia.

${ }^{3}$ School of Earth and Environmental Sciences, University of Western Australia, 35 Stirling Highway, Crawley, Western Australia 6009, Australia.
\end{abstract}

\begin{abstract}
Sixteen species of molluscs are described from the Late Eocene Merlinleigh Sandstone, Carnarvon Basin, Western Australia. The assemblage, a random thanatocoenose, is dominated by bivalves (11 species) and a cephalopod, with a few gastropod specimens. All primary shell carbonate - calcite or aragonite - is replaced by silica. The assemblage is distinctive in composition, resembling no other known from the Australian Eocene. Terrestrial plant material, all silicified, is associated with the marine fossils, consistent with a depositional environment of the energised sandy littoral, subject to river flood discharge. At a height of +280 to $300 \mathrm{~m} \mathrm{AHD,} \mathrm{the} \mathrm{formation} \mathrm{compares} \mathrm{closely} \mathrm{with} \mathrm{others}$ of similar age in southwestern Australia, which also consist of a combination of marine and terrestrial fossil material. Faunal affinities with the southern Australian Eocene were weak; an apparent TethyanIndo-Southwest Pacific influence is present, possibly with a weak endemic element. The taxonomy of the nautiloid Aturia clarkei is discussed.
\end{abstract}

KEYWORDS: new species, fossils, Tethyan-Indo-Southwest Pacific influence, silicification, Aturia.

\section{INTRODUCTION}

This paper continues studies by the authors (Darragh and Kendrick 1980, 2000, 2008) on the Eocene molluscan faunas of southern and western Australia, herein with regard to the most northerly of these, from the Merlinleigh Sandstone, eastern Carnarvon Basin (Playford et al. 1975 and references; Cockbain 1981). The formation is a thin (up to $15 \mathrm{~m}$ ), transgressive, poorly cemented, silicified quartz sandstone with subordinate siltstone and conglomerate, exposed discontinuously between the Gascoyne and Lyndon Rivers, near the northern margin of the Yilgarn Block (Johnstone et al. 1973), with the most productive outcrops located in and adjacent to the Kennedy Range. At the type section $\left(24^{\circ} 18^{\prime} 50^{\prime \prime} \mathrm{S}, 115^{\circ} 11^{\prime} 10^{\prime \prime} \mathrm{E}\right)$, located at a mesa $1.6 \mathrm{~km}$ ESE of the abandoned Merlinleigh Station homestead, the formation is $9.1 \mathrm{~m}$ thick. The formation unconformably overlies Permian units and is overlain in turn by either Tertiary laterite or by a conspicuous aeolian dune field of possible Quaternary age.

Fossil material, invariably silicified, occurs mainly as surface float on and below erosion scarps and comprises, at present knowledge, foraminifers, colonial corals, bryozoans, hydrozoans, molluscs, fossil wood (some teredine-bored) and other terrestrial plant remains, likewise silicified (Teichert 1944; Pulley 1959; Brunnschweiler 1962; Cockbain 1981; McNamara and Scott 1983; Haig and Mory 2003). Other than the nautiloid Aturia clarkei Teichert, 1944, molluscs from the Merlinleigh Sandstone have thus far remained undescribed, notwithstanding their ready collection and often excellent preservation. However, the gastropods and nautiloids, in particular, have undergone moderate to severe mechanical abrasion and transportation. All bivalves of whatever facies (teredines excepted) are known only from single, disarticulated valves. As a whole, the material forms a randomly disassociated death assemblage.

This assemblage of molluscs and that from the Kalbarri area sandstone differ from the other known Late Eocene faunas of Australia, as none of the others represents a shallow water fauna inhabiting a sandy substrate (Darragh and Kendrick 2008). Somewhat similar types of facies are known in the late Tertiary.

\section{MATERIAL}

The study material has been drawn from the 
palaeontological collections of the Western Australian Museum (WAM), Museum Victoria (NMV) and the E. de C. Clarke Earth Sciences Museum, The University of Western Australia (UWA). The registration numbers of Western Australian Museum animal fossil specimens accessed before June 1959 bear the prefix $G$ and subsequently are prefixed by the last two digits of the current year of registration; those of plant specimens are prefixed by $\mathrm{P}$ and the last two digits of the current year of registration.

Most of this material represents five collection events, all from Western Australia, as follows:

1. Collection of C. Teichert. From east side of Kennedy Range, 1.3 miles $(2.1 \mathrm{~km})$ north of Merlinleigh homestead, Carnarvon Basin, W.A.

UWA 21406 - holotype of Aturia clarkei Teichert, 1944

UWA $21407 \mathrm{a}-\mathrm{e}$ - paratypes of $A$. clarkei. Paratypes UWA 21407a \& b missing, November 2008

2. Collection of R. Savage and W.D.L. Ride, 5-7.ix.1967. Merlinleigh Station, from and adjacent to type section of Merlinleigh Sandstone.

Map ref. Kennedy Range 312973. WAM 69.27469.290 .

3. Collections by the present authors:

i. 10.iv.1969. Lyndon Station, three miles (c. 5 km) WNW from Ebra Well, surface float. Map ref. Winning Pool 289063. WAM 70.1693, 70.1694.

ii. 13.iv.1969. Surface float on sides of mesa $1.6 \mathrm{~km}$ ESE from Merlinleigh Station homestead (= type section of Merlinleigh Sandstone). Map ref. Mount Sandiman LU 175087. WAM 70.1665-70.1677. NMV P314122-314134, P31429-314297, 314894314896.

iii. 13.iv.1969. Surface float on side of mesa c. $200 \mathrm{~m}$ $\mathrm{N}$ of type section of Merlinleigh Sandstone. WAM 70.1678-70.1692.

4. Collections by the present authors with K.J. McNamara, 31.viii-1.ix.1979.

i. Side of breakaway $1.5 \mathrm{~km}$ E of old Merlinleigh station homestead; $200 \mathrm{~m} \mathrm{~N}$ of type section mesa, Merlinleigh Sandstone. Map ref. Mount Sandiman LU 175087. WAM 79.2856-79.2887. P.79.46-P.79.50. NMV P314290-314293, 314306, 315059.

ii. Merlinleigh Station. Side of escarpment $0.8 \mathrm{~km} \mathrm{~N}$ from type section mesa, Merlinleigh Sandstone. Map ref. Kennedy Range 312975. WAM 79.288979.2891. P.79.42, P.79.43. The type locality for Banksia archaeocarpa McNamara and Scott, 1983.

iii. Merlinleigh Station. Side of escarpment immediately $\mathrm{S}$ of track $1.5 \mathrm{~km} \mathrm{NNE}$ of old Merlinleigh homestead. Map ref. Kennedy Range
312977. WAM 79.2892-79.2898. P.79.51. P314294314297.

iv. Mt Sandiman Station. Small mesa $2 \mathrm{~km} \mathrm{SE} \mathrm{of}$ type section of Merlinleigh Sandstone. Site is close to boundary with Merlinleigh Station. Map ref. Kennedy Range 314974. WAM 79.2902. P.79.53. P315054.

v. Mt Sandiman Station. Hill $1 \mathrm{~km}$ and $120^{\circ}$ from type section mesa of Merlinleigh Sandstone. Float on northern hill slopes. Map ref. Kennedy Range 313974. WAM 79.2899, 79.2900. P79.52.

5. Collections by present authors with K. Ayyasami (Geological Survey of India), 8,9.ix.1996.

i. Eroded lower slope of mesa $1.6 \mathrm{~km}$ ESE of old Merlinleigh homestead. Map ref. Mt Sandiman (1:100,000 sheet) LU 176087. WAM 97.1-97.8, P.97.1-P.97.6. NMV P314112-314121, P315512.

ii. Erosion slope $1.5 \mathrm{~km} \mathrm{NNE}$ of old Merlinleigh homestead; between $0.4 \mathrm{~km}$ and $0.1 \mathrm{~km} \mathrm{~N}$ of pass. Map ref. Mt Sandiman (1:100,000 sheet) LU 165111. WAM 97.9-97.12, P.97.7. NMV P314294-7.

iii. Other records, some, possibly all, of which may be manuports.

6. Two fragments of an Aturia shell from an Aboriginal campsite on Eudamullah Station, said to have been bought there from Merlinleigh. Presented by A. Snell and accessed 14.ii.1942. WAM G16008.

7. Four shell fragments of Aturia from 'surface of valley containing Bangemall goldmine'. Presented by M. Greening and accessed October 1966. WAM 66.100866.1011 .

8. Two shell fragments of Aturia found on Moogooree Station by Mrs F.S. Dodds. Accessed 9.xii.1977. WAM 78.641-2.

9. Part of an Aturia shell retaining a remnant of its outer layer, found by J. Glass in the Kennedy Range. Presented via the Geraldton Regional Museum and accessed 24.viii.1988. WAM 88.849.

\section{AGE AND CORRELATION}

A Miocene age for the Merlinleigh Sandstone was initially proposed by Teichert (1944), after Chapman and Crespin (1934), from the shared presence of the nautiloid Aturia clarkei Teichert with the Pallinup Formation (= Plantagenet Beds) of the Bremer Basin, which with the Kennedy Range Tertiary strata were subsequently correlated by Glaessner (1955) with the Late Eocene Tortachilla Limestone and Blanche Point Formation of the St Vincent Basin. From a study of the fibulariid echinoids, Brunnschweiler (1962) favoured an Eocene ('Late Cuisian or Lutetian') age for the formation. Further, from the presence of foraminifers Maslinella chapmani Glaessner and Wade, Operculina sp., Crespinina kingscotensis Wade and Rotalia sp., 
TABLE 1 All molluscan taxa known from the Merlinleigh Sandstone, listed in taxonomic order together with the total numbers of each examined.

\begin{tabular}{lc} 
BIVALVIA & Total specimens \\
\hline Cucullaea sp. cf. C. adelaidensis Tate, 1886 & 2 \\
Glycymeris sp. cf. G. cainozoica (Tenison Woods, 1877) & 99 \\
Spondylus sp.cf. S. gaderopoides McCoy, 1876 & 2 \\
Pectinid, genus and species undetermined & 1 frag. \\
“Ostrea' sp. & 1 \\
Chama sp. & 23 \\
Miltha sp. & 2 frags \\
Venericardia capricornia sp. nov. & 61 \\
Periglypta weegeeree sp. nov. & 4 \\
Dosinia (Kereia) numerosissima sp. nov. & 121 \\
Teredinid, genus and species undetermined & 10 \\
GASTROPODA & \\
\hline Tugali? sp. & 5 \\
Turbo (Euninella) sp. cf. T. (E.) hamiltonensis Harris, 1897 & 3 \\
Vasum sp. & 3 \\
Zelandiella? sp. & 1 \\
CEPHALOPODA & 1 \\
\hline Aturia clarkei Teichert, 1944 & \\
\hline
\end{tabular}

Cockbain (1981) confirmed a Late Eocene age for the Merlinleigh Sandstone, correlated in part with the Late Eocene Giralia Calcarenite of the Carnarvon Basin, the latter deposited under 'open ocean conditions'.

The nearshore features of the Merlinleigh Sandstone are matched by others of similar age and elevation in southwest Australia, as has been noted by Johnstone et al. (1973). An example of this, hitherto unreported, has been recognized in an exposure of the Plantagenet Group located on a low divide between the Gordon and Pallinup Rivers, $13 \mathrm{~km}$ ENE of Tambellup $\left(34^{\circ} 02^{\prime} \mathrm{S}, 117^{\circ} 38^{\prime} \mathrm{E}\right)$. Lithologies present include (a) a dark brown, conglomeratic, coarse-grained sandstone with impressions of marine bivalves and (b) a pallid, fine-grained spongolite with impressions of terrestrial vegetation (WAM records). Contour maps of the area (Martinup SW $1: 25,000$ series) show that the site lies at or very close to $+300 \mathrm{~m}$ AHD.

\section{DEPOSITIONAL ENVIRONMENT}

Plant debris in the Merlinleigh Sandstone includes araucarian cones, proteaceous leaves, wood, a Banksia fructescence and other material (McLoughlin and Hill 1996). This, in close association with an assortment of marine fossils dominated by disarticulated bivalves from a shallow sandy infaunal habitat, indicates a depositional environment featuring 'local rivers in flood, depositing the poorly sorted sands and the plant material close to a marine sand bar' (McNamara and Scott 1983: pp. 186-187). The presence of rare very worn and damaged specimens of a turbinid gastropod and limpet are indications of transport of specimens from some distant rocky or hard ground habitat. The Aturia specimens suggest strandings on a shallow beach exposed to the open ocean; the extensive damage to almost all the specimens, particularly to the body chamber, suggests some kind of predation at sea involving large fish or cetaceans.

\section{SYSTEMATIC PALAEONTOLOGY}

Class Bivalvia Linneaus, 1758

Family Cucullaeidae Stewart, 1930

Genus Cucullaea Lamarck, 1801

\section{Cucullaea sp. cf. C. adelaidensis Tate, 1886}

Figures $1 \mathrm{G}, \mathrm{H}, \mathrm{K}$

cf. Cucullaea adelaidensis Tate, 1886: 144, plate 11, figures $14 \mathrm{a}, \mathrm{b}$.

\section{MATERIAL EXAMINED}

Australia: Western Australia: Kennedy Range. WAM 97.1, one LV. WAM 97.9, one RV. NMV P314302, 
marginal fragment of LV. NMV P314113, fragment of $\mathrm{LV}$. Total of one LV, one RV and fragments.

\section{DESCRIPTION}

Valves of about normal size for genus, possibly less than fully mature; robust, obliquely trapezoidal, inflated, longer than high; umbones prominent, strongly incurved, orthogyrous; LV apparently more inflated and with a more elevated, prominent umbo than RV. Lateral teeth parallel to dorsal margin, not descending; ventral margin of LV strongly internally crenulate, RV apparently less so. Sculpture finely, closely radiate with subordinate commarginals, that appear to be finer on LV. Myophoric flange present (LV); adductor scars commarginally ridged; ligament with two grooves.

\section{DIMENSIONS}

$\begin{array}{llll} & \text { Length } & \text { Height } & \text { Inflation } \\ \text { WAM 97.1 LV } & 43.2 & 37.5 & 16.3 \\ \text { WAM 97.9 RV } & 44.4 & 35.8 & 14.4\end{array}$

\section{REMARKS}

The limited available material, consisting of single left and right valves representing different individuals, is, in general features (size, sculpture etc), similar to Cucullaea adelaidensis Tate (type series illustrated by Singleton 1932: 304, plate 26, figures 21-24; Ludbrook 1965:102, plate 4, figures 11-15) from 'glauconitic sands, Adelaide [= Kent Town] bore', now assigned to the Blanche Point Formation. Tate's species is also recorded from the Late Eocene Upper Browns Creek Clay of Victoria (Darragh 1985:111). Decalcified moulds of a species of Cucullaea (WAM 89.312, WAM 89.313) resembling C. adelaidensis and the present species are known from the Pallinup Formation near Mount Barker, Western Australia.

Small discrepancies in shell proportions and some other features are noted in the study material from Merlinleigh. Their significance, if any, remains to be clarified.

\section{OCCURRENCE}

Merlinleigh Sandstone. Late Eocene.

Family Glycymerididae Newton, 1916

Genus Glycymeris da Costa, 1778

\section{Glycymeris sp. cf. G. cainozoica (Tenison Woods, 1877)}

Figures 1B, C

cf. Cucullaea cainoizoica Tenison Woods, 1877: 111.

\section{MATERIAL EXAMINED}

Australia: Western Australia: Kennedy Range. WAM 69.281 (4 valves), 70.1667 (1), 70.1668 (9), 70.1684 (1), 79.2856 (4), 79.2893 (8), 97.2 (5), 97.10 (2); NMV P314115 (7), P314131 (4), P314292 (21), P314294 (9), P314298 (14). Total of 99 single valves.

\section{DESCRIPTION}

Of medium size for genus, subcircular, slightly longer than high; umbo orthogyrous, moderately inflated, beak small, slightly elevated, a little anterior of centre, margin rounded anteriorly, subangulate and slightly extended posteriorly. Ligamental area narrow, with 4-14 insertion grooves, the anterior series being the greater. Hinge with two prominent, subhorizontal series with the posterior the larger, median teeth very fine. Hinge encroached upon by expansion of ligamental area. Internal margin strongly crenulate from anterior to posterior extremities. Anterior adductor scar subcircular, bordered by a groove; posterior adductor scar D-shaped, bordered by low myophoral flange; both scars commarginally ridged. External sculpture of numerous very fine radial costellae, arranged in groups of six and seven, the groups offset by slightly deeper, wider grooves; weak intercostal, commarginal striae visible on some specimens.

\section{DIMENSIONS}

$\begin{array}{llll} & \text { Length } & \text { Height } & \text { Inflation } \\ \text { WAM 70.1667 RV } & 26.9 & 25.3 & 8.9 \\ \text { WAM 70.1668 LV } & 34.0 & 33.7 & 13.5 \\ \text { WAM 79.2856 RV } & 28.6 & 26.3 & 8.2\end{array}$

\section{REMARKS}

The study material, which provides the earliest record for the genus from Western Australia, has some resemblance to Glycymeris cainozoica (Tenison Woods, 1877) from the Early Miocene Freestone Cove Sandstone of Table Cape, near Wynyard, northern Tasmania and which has been recorded from the Late Eocene to Middle Miocene (Chapman and Singleton 1925: 20-22 plate 1, figures 1-4, plate 4, figures 1-3; Ludbrook 1965: 87; Ludbrook 1967: 65, plate 1, figures 7-12) of southeastern Australia.

The sculpture of Merlinleigh specimens is very similar to that of topotypes of Tenison Woods' species but these latter seem to have more teeth than do specimens of equal size in the present material; Merlinleigh specimens are very slightly trigonal in shape and are more produced on the posterior flank, compared with specimens (including topotypes) of $G$. cainozoica from southeastern Australia, which are more roundly equilateral in outline.

Though not uncommon on weathered outcrops around Merlinleigh, the present species is known only from single valves, often broken and/or much abraded. Comparison of a size-range of well-preserved specimens from Merlinleigh would clarify relations with the Tenison Woods species, which are for the present deferred.

The spelling of the specific name by Tenison Woods as cainoizoica has been assumed to be a printing error for cainozoica by all subsequent authors and in terms of Article 33.3.1 of the International Code of Zoological Nomenclature (Fourth edition) the latter spelling is maintained. 

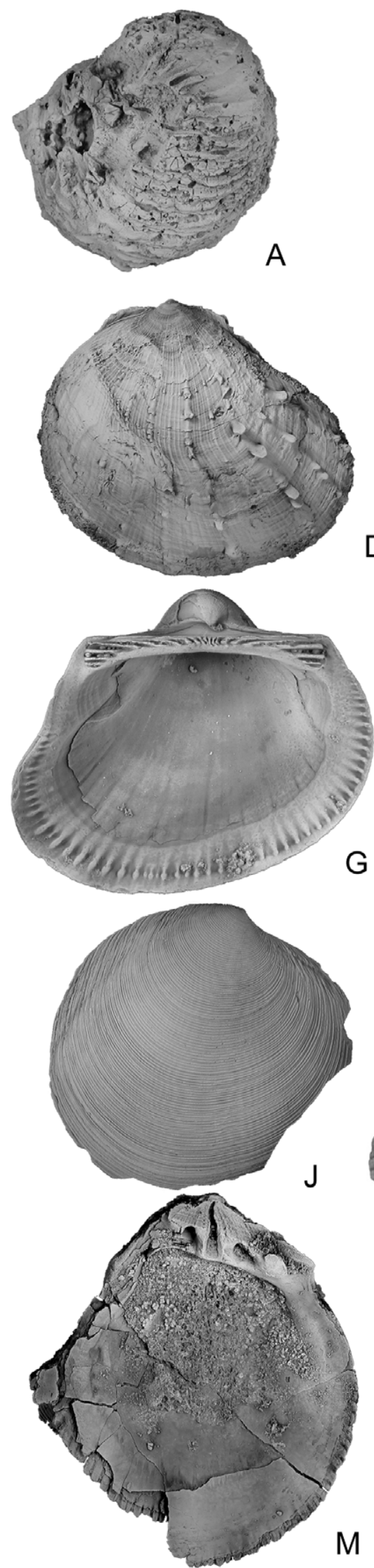

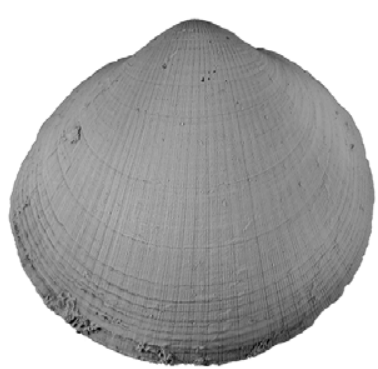

B

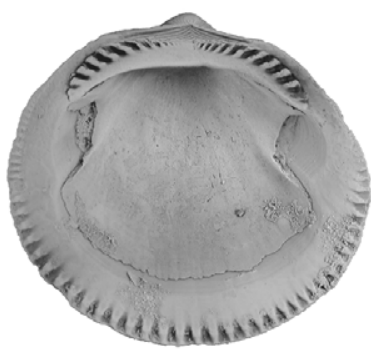

C

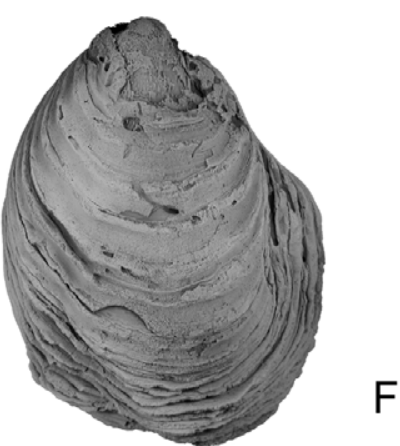

$\mathrm{F}$

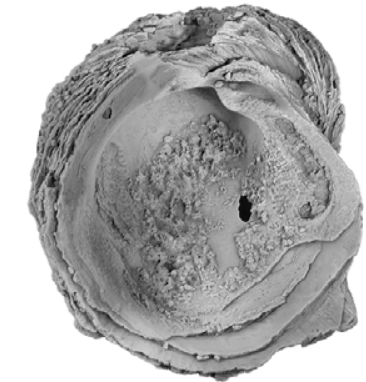

$\mathrm{E}$
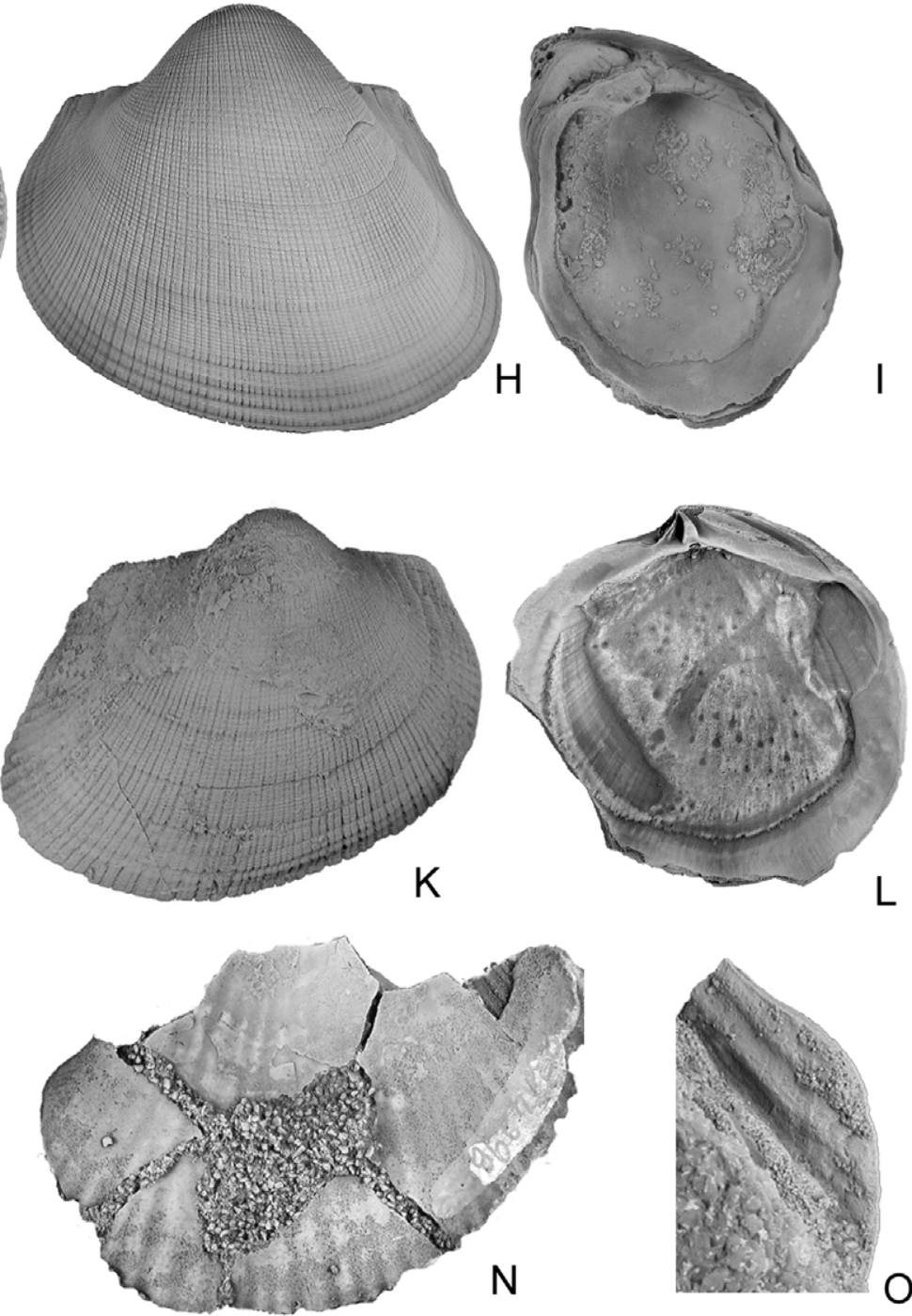

FIGURE 1 A, E, F, I, Chama sp.: A, E, WAM 97.3 (x 0.9); F, I, WAM 97.3 (x 0.8); B,C, Glycymeris sp. cf. G. cainozoica (Tenison Woods, 1877): B, C, WAM 70.1667 (x 1.3); D, M, Spondy/us sp. cf. S. gaderopoides McCoy, 1876: D, NMV P314116 (x 0.9); M, WAM 69.282 (x 0.8); G, H, K, Cucullaea sp. cf. C. adelaidensis Tate, 1886: G, H, WAM 97.1 (x 1.1); K, WAM 97.9 (x 1.1); J, L, Miltha sp.: J, L, NMV P314122 (x 1.0); N, O, Pectinid, genus and species undetermined: N, O, NMV P314298 N (x 1.3), O (x 3.4). 
OCCURRENCE

Merlinleigh Sandstone. Late Eocene.

Family Spondylidae Gray, 1826

Genus Spondylus Linnaeus, 1758

Spondylus sp. cf. S. gaderopoides McCoy, 1876

Figures 1D, M

cf. Spondylus gaderopoides McCoy, 1876: 27, plate 38, figures $1 \mathrm{a}-\mathrm{d}$.

\section{MATERIAL EXAMINED}

Australia: Western Australia: Kennedy Range. WAM 69.282 LV. NMV P314116 LV. Total of two specimens.

\section{DESCRIPTION}

The specimens to hand are of small size both for the genus and for McCoy's species. LV irregularly convex, rounded anteriorly and extended posteriorly; beak small, projecting slightly above short and weakly alate dorsal margin. Externally (LV) there are ten larger radial costae, bearing prominent, erect scales; the intercostal spaces have five to seven finer costellae and are crossed by coarse, commarginal growth lines. Ligament is internal, in a deep, elongate resilifer, on each side bounded by isodont crura; where preserved, internal margin moderately crenulate; adductor scar obscured.

\section{DIMENSIONS}

$\begin{array}{llll} & \text { Length } & \text { Height } & \text { Inflation } \\ \text { WAM 69.282 LV } & \text { c. } 54 & 63 \text { (est.) } & - \\ \text { NMV P314116 LV } & 52.6 & 48 & 15 \text { (est.) }\end{array}$

\section{REMARKS}

Since its description by McCoy (1876) from the Oligocene of Bird Rock Bluff, Torquay (Otway Basin), S. gaderopoides has been recorded from numerous Middle Eocene to Middle Miocene sources across southern Australia (Tate 1886:121; 1899:275; Lowry 1970: 66, 107, figures 20, 27E, 28; S. sp. cf. $S$. gaderopoides McCoy, Darragh and Kendrick, 1980: 15, figure 4 A, B). Specimens with sculpture very similar to that of specimen NMV P314116 (Figure 1D) occur in the Middle-Upper Tortachilla Limestone of the St Vincent Basin (NMV collection) and, further west, the species occurs in the Wilson Bluff and Abrakurrie Limestones and the Colville Sandstone of the Eucla Basin. Small specimens attributable to this variable species occur in the Eocene Pallinup Formation and Nanarup Limestone of the Bremer Basin (Darragh and Kendrick 1980 and WAM collection). The present specimens extend these confirmed or provisional records northward into the Carnarvon Basin.

\section{OCCURRENCE}

Merlinleigh Sandstone. Late Eocene.

\section{Family Pectinidae Rafinesque, 1815}

\section{Genus and species undetermined}

Figures $1 \mathrm{~N}, \mathrm{O}$

\section{MATERIAL EXAMINED}

Australia: Western Australia: Kennedy Range. NMV P314298, fragmentary single valve.

\section{DESCRIPTION}

Little remains of the specimen beyond the internal surface extending to the ventral margin and to either the anterior or posterior margin of a medium sized pectinid. The valve is rather flat with numerous simple, wide radial costae, about as wide as the interspaces. Two very small, visible areas of the external surface show simple radial costae.

\section{DIMENSIONS}

The specimen has a length of $43 \mathrm{~mm}$. Estimated original length c. $48 \mathrm{~mm}$.

\section{REMARKS}

The simple style of ribbing, so far as can be observed, resembles that of the $\mathrm{LV}$ of the flindersi form of Talochlamys eyrei (Tate, 1886), a widespread species across southern Australia from Aldingan to Longfordian (Beu and Darragh 2000: 101-106, Figures 31B, C, E, G, I; 32G; 33A-E; 34A-G). The identity of this, the sole known pectinid from the Merlinleigh Sandstone, awaits the collection of further, better preserved material.

\section{OCCURRENCE}

Merlinleigh Sandstone. Late Eocene.

\section{Family Ostreidae Rafinesque, 1815}

\section{'Ostrea' sp.}

Figures 2F, J, L

\section{MATERIAL EXAMINED}

Australia: Western Australia: Kennedy Range. NMV P314124. 1 LV.

\section{DESCRIPTION}

A single, small, ostreiform LV, partly overlain on inner and outer surfaces by silicified sandstone. The valve is worn, higher than wide and showing evidence of an elongate, partly infilled attachment area. The resilifer is shallow and triangular; catachomata present on anterior dorsal margin.

\section{DIMENSIONS}

$\begin{array}{llll} & \text { Length } & \text { Height } & \text { Inflation } \\ \text { NMV P314124 } & 25 \text { (est.) } & 33 & 12 \text { (est.) }\end{array}$




\section{REMARKS}

The specimen is poorly preserved and reliable identification even to generic rank is questionable.

\section{OCCURRENCE}

Merlinleigh Sandstone. Late Eocene.

Family Chamidae Lamarck, 1809

Genus Chama Linnaeus, 1758

\section{Chama sp.}

Figures $1 \mathrm{~A}, \mathrm{E}, \mathrm{F}, \mathrm{I}$

\section{MATERIAL EXAMINED}

Australia: Western Australia: Kennedy Range. WAM 70.1686 (3 specimens), 79.2858 (1), 97.3 (2), 97.4 (5). NMV P314126 (5), P314174 (4), P314301 (3). Total of 23 specimens.

\section{DESCRIPTION}

Up to normal size for genus, thick and robust, mostly somewhat abraded, irregular in shape, subcircular to dorsoventrally elongate in outline, inequivalve, LV the larger, internally concave with small umbonal attachment area; valves weakly coiled with prosogyrous umbones, bordered on posterior flanks by shallow radial depressions. Sculpture foliaceous, of irregular strength and spacing, on which a weak, close, radial microsculpture is occasionally visible. Hinge of LV with large, horizontal, blade-like, weakly serrate tooth; $\mathrm{RV}$ with weak corresponding socket; ligamental area of LV arched. Anterior adductor scar of RV very elongate, much higher than wide; posterior adductor scar of RV wider and shorter than anterior scar, D-shaped. Adductor scars in LV matching in size and shape.

\section{DIMENSIONS}

$\begin{array}{llll} & \text { Length } & \text { Height } & \text { Inflation } \\ \text { WAM 97.3a RV } & 38.5 & 49.3 & 19.5 \\ \text { WAM 97.3b LV } & 36.3 & 49.4 & 19.0\end{array}$

\section{REMARKS}

Chama lamellifera Tenison Woods, 1877, originally described from the Early Miocene of Table Cape, Tasmania, ranges from Late Eocene to Bairnsdalian and is smaller and much more thinly shelled than the study material, with a finer commarginal and radial sculpture. It appears to be confined to the Otway and St Vincent Basins (Ludbrook 1955: 46; Darragh 1985: 111).

In its robust form and shape the Merlinleigh species has some resemblance to Chama ruderalis Lamarck, 1819 (Recent Australia and Late Miocene to Pleistocene New Zealand (Beu 2006: 217, figure 16), and to C. subgigas d'Orbigny, 1850, Lutetian, Paris Basin.

\section{OCCURRENCE}

Merlinleigh Sandstone. Late Eocene.
Family Lucinidae Fleming, 1828

Genus Miltha H. and A. Adams, 1857

\section{Miltha sp.}

Figures 1J, L, 3E

\section{MATERIAL EXAMINED}

Australia: Western Australia: Kennedy Range. NMV P314122. Two fragmentary RVs.

\section{DESCRIPTION}

Small for genus, subcircular, a little shortened (also broken) anteriorly; umbo prosogyrous, beak short, directed anteriorly; margin convexly rounded behind beak, slightly concave immediately anterior to beak. Sculpture of fine, regular, closely-set commarginal costae, with a prominent radial groove extending from beak to posterior margin of disc. Ligament recessed, set upon a broad hinge plate; cardinals two, bifid. Anterior adductor scar elongate ( $20 \times 5 \mathrm{~mm}$ ), close to pallial line; posterior adductor scar ovate $(11 \times 7 \mathrm{~mm})$. Pallial line entire, strongly defined; internal margin, where retained, smooth.

\section{DIMENSIONS}

$\begin{array}{llll} & \text { Length } & \text { Height } & \text { Inflation } \\ \text { NMV P314122 RV } & 39.3 & 37.3 & 7.3\end{array}$

\section{REMARKS}

Australian records of the genus Miltha have been confined hitherto to the Miocene and Pliocene of the Eucla, St Vincent, Otway and Gippsland Basins (Ludbrook 1969; Beu and Darragh 2001). The present material extends the geographic and stratigraphic ranges of the genus to the Late Eocene of the Carnarvon Basin.

We here report the recognition of specimens of a species of Miltha from the Pliocene-Pleistocene 'Older' Ascot Formation of the Perth Basin (Playford et al. 1975; Kendrick et al. 1991). Being entirely subsurface, all material from the formation has been acquired by percussion drilling and sludge pump extraction from water bores and in the case of Miltha specimens, is fragmentary. The best specimens (WAM 94.1029, 98.507, 00.354), of undoubted generic provenance, are from bores in the West Gingin district, c. $70 \mathrm{~km} \mathrm{~N}$ of Perth. Other relevant localities are Canning Vale, Pinjar and Thornlie, all located in the eastern part of the metropolitan Perth Basin. Specific determination of this Ascot Formation material is deferred. It appears to be distinct from $M$. hamptonensis Ludbrook from the Roe Calcarenite.

In New Zealand, Miltha is recorded from the Early Paleocene (Wangaloan) to Late Pliocene (Waipipian) (Beu and Maxwell 1990).

\section{OCCURRENCE}

Merlinleigh Sandstone. Late Eocene. 

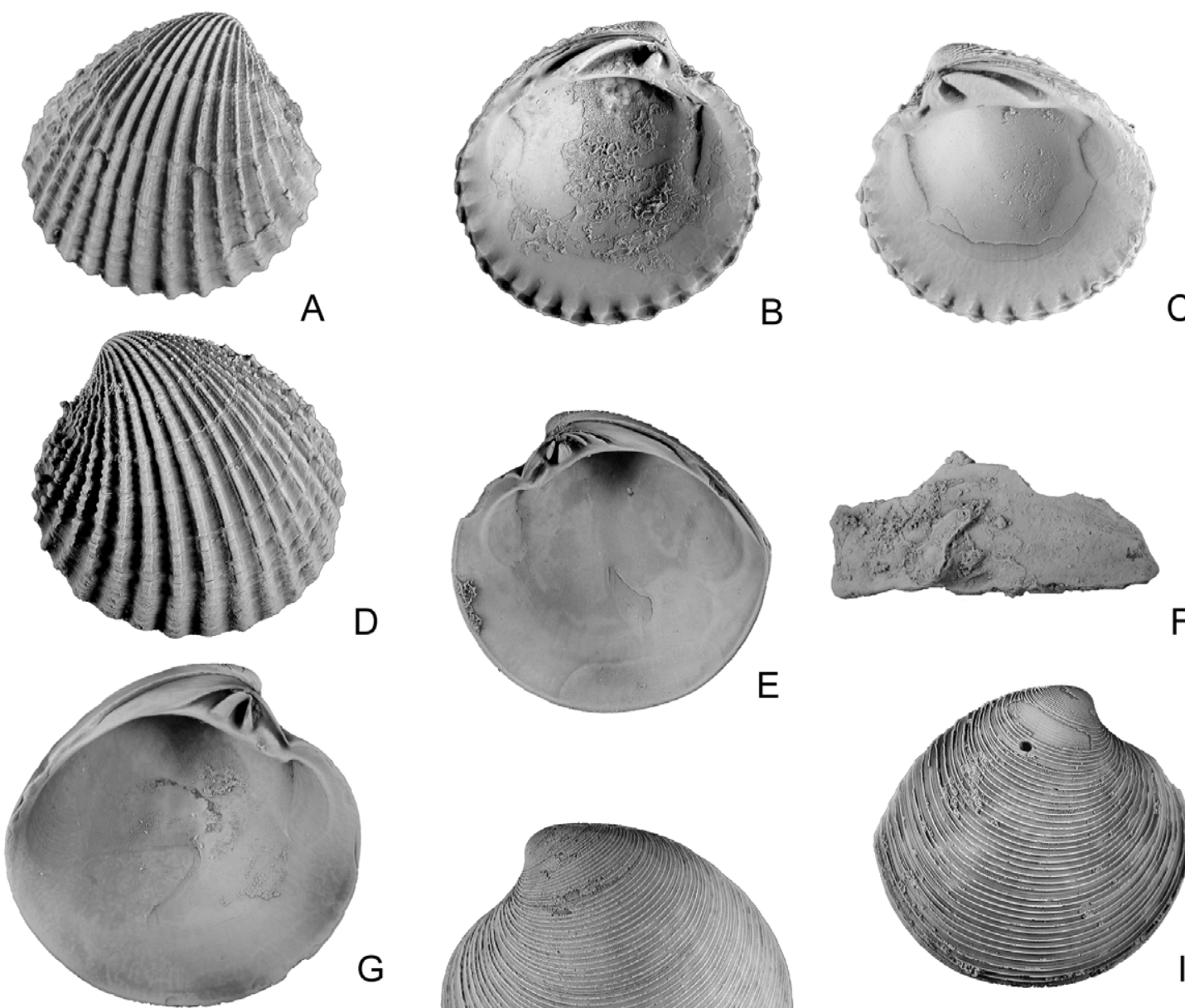

$\mathrm{E}$
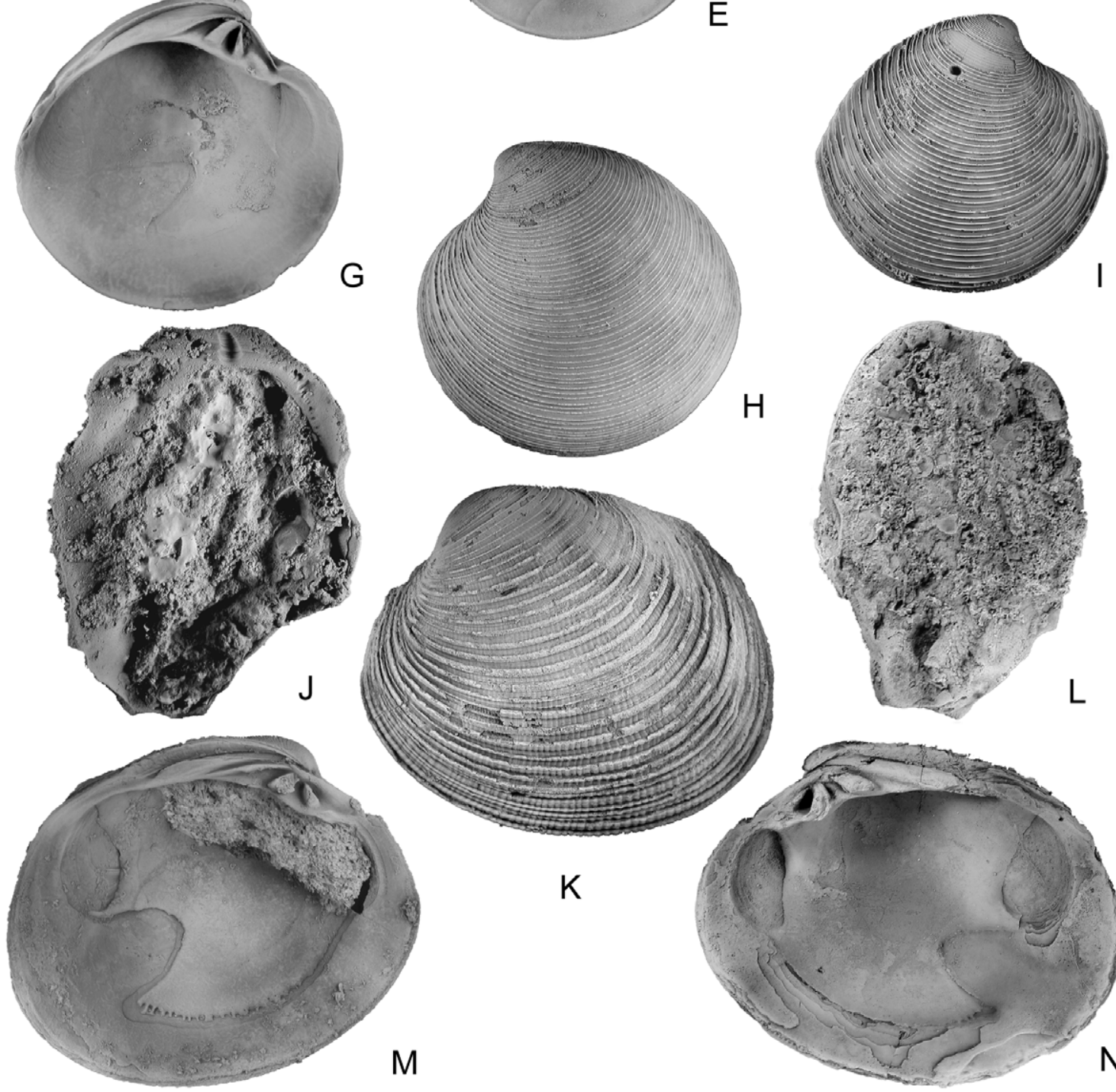

$\mathrm{M}$

FIGURE 2 A, B, C, D, Venericardia capricornia sp. nov.: A, C, WAM 79.2857b (x 2.1) paratype; B, D, WAM 78.2857a (x 2.1) holotype; E, G, H, I, Dosinia (Kereia) numerosissima sp. nov.: E, I, WAM 97.6d (x 1.2) paratype; G, H, WAM 97.6a (x 1.2) holotype; F, J, L, 'Ostrea' sp.: F, J, L, NMV P314124, F (x 1.2), J, L (x 1.2); K, M, N, Periglypta weegeeree sp. nov.: K, M, WAM 79.2860b (x 0.8) holotype; N, WAM 79.2889 (x 0.8) paratype. 
Family Carditidae Fleming, 1828

\section{Genus Venericardia Lamarck, 1801}

\section{Venericardia capricornia sp. nov.}

Figures 2A-D, 3C, D

\section{MATERIAL EXAMINED}

\section{Holotype}

Australia: Western Australia: WAM 79.2857a $\mathrm{LV}$, from Kennedy Range. $1.5 \mathrm{~km} \mathrm{E}$ of abandoned Merlinleigh homestead (type section of Merlinleigh Sandstone). Mount Sandiman LU 175087.

\section{Paratypes}

WAM 79.2857b-f 2LVs 3RVs. NMV P315512 RV.

\section{Other material}

WAM 70.1669 (2 specimens), 70.1685 (6), 97.4 (5), NMV P314112 (6), P314128 (9), P314293 (11), P314296 (3), P314305 (11). Total of 61 single valves.

\section{DESCRIPTION}

Up to medium size for genus, usually (present material) less so, robust, roundly subquadrate in outline, slightly higher than long; umbones prosogyrous, beaks incurved; with 22-26 strong, sharp, radial costae, which expand relative to the interspaces with growth; radials crossed by commarginal growth striae, producing weak scales. Ligament submarginal, narrow; lunule small, deeply set. Anterior adductor scar narrow, elongate, exceeding in length the posterior scar, which is ovate in profile. Pallial line between scars prominent. Internal margins strongly crenulate, corresponding to the costal interspaces.

Hinge with cardinals only, three in each valve; LV with long, thin posterior tooth with narrow groove along crest, a small triangular central tooth and a weak or obsolete anterior cardinal; RV with reduced, triangular cardinal, prominent, strong, elongate, triangular central cardinal and a long, thin, posterior cardinal. Laterals obsolete.

\section{DIMENSIONS}

$\begin{array}{ccccc} & \text { Length } & \text { Height } & \text { Inflation } & \text { Costae } \\ \text { WAM 79.2857a LV, holotype } & 17.5 & 18.0 & 6.7 & 25 \\ \text { WAM 79.2857b RV, paratype } & 16.1 & 16.1 & 6.4 & 24 \\ \text { WAM 79.2857c LV, paratype } & 16.9 & 18.5 & 7.1 & 22 \\ \text { WAM 79.2857d LV, paratype } & 17.7 & 17.1 & 6.3 & 21+ \\ \text { WAM 79.2857e RV, paratype } & 17.3 & 17.5 & 7.1 & 22 \\ \text { WAM 79.2857f RV, paratype } & 17.0 & 17.9 & 7.0 & 22 \\ \text { NMV P315512 RV, paratype } & 33.3 & 31.2 & 11.6 & 26\end{array}$

\section{REMARKS}

The species lacks any known congener in the Australasian Tertiary and its affinities would appear to lie in all probability with the carditids of the tropical - Tethyan Paleogene, such as Venericardia imbricata (Gmelin), the type species of the genus, from the
Lutetian of the Paris Basin. The hinge of the present species is very similar to that of $V$. imbricata.

The genus Venericardia has been utilized in the past to accommodate small carditids from the Tertiary of southern Australia and New Zealand, such as 'Cardita' latissima Tate (Darragh and Kendrick 1980, 2000 for synonymy). This and other such taxa, which have much more prosogyrous umbones and more prominent spines and scales, seem better located generically as Glyptoactis (Fasciculicardia) (Darragh and Kendrick 2008: 226).

The specific name recognizes the proximity of the Kennedy Range to the Tropic of Capricorn.

\section{OCCURRENCE}

Merlinleigh Sandstone. Late Eocene.

\section{Family Veneridae Rafinesque, 1815}

\section{Genus Periglypta Jukes-Brown, 1914}

Periglypta weegeeree sp. nov.

Figures 2K, M-N, 3F, G

\section{MATERIAL EXAMINED}

\section{Holotype}

Australia: Western Australia: WAM 79.2860b LV, from Kennedy Range, Western Australia. West side of erosion scarp $1.5 \mathrm{~km}$ E of old Merlinleigh homestead and c. $200 \mathrm{~m} \mathrm{~N}$ of type section of Merlinleigh Sandstone. Map ref. Kennedy Range 312974.

\section{Paratypes}

WAM 79.2860a RV; 79.2889 RV.

\section{Other material}

WAM 70.672, fragmentary LV; 70.1688, RV. NMV P314123, 3 fragments; P314120, 1 fragment; P314304, 1 fragment. Total of 4 single valves and 6 (single) fragments.

\section{DESCRIPTION}

Up to normal size for genus, robust, roundly subquadrate, longer than high, strongly prosogyrous, beak incurved; lunule shallow, defined by an incised border; escutcheon more evident on LV where there is a distinct radial groove; sculpture of prominent, close, commarginal lamellae, slightly recurved dorsally and crenulated by numerous, fine, close-set radial costellae; internal margin of valves smooth. Pallial sinus wide, rounded. Adductor scars ovate, higher than long.

\section{DIMENSIONS}

Length Height Inflation

$\begin{array}{llll}\text { WAM 79.2860b LV holotype } & 62.5 & 52.0 & 19.2 \\ \text { WAM 79.2860a RV paratype } & 55.5 & 50.0 & 18.0 \\ \text { WAM 79.2889 RV paratype } & 63.0 & 54.5 & 19.5\end{array}$



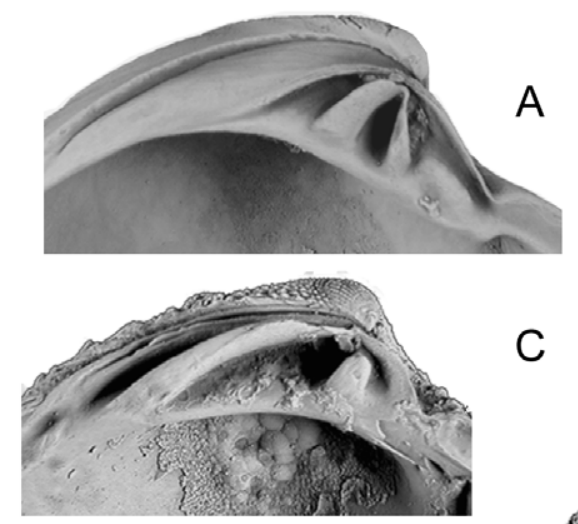

C
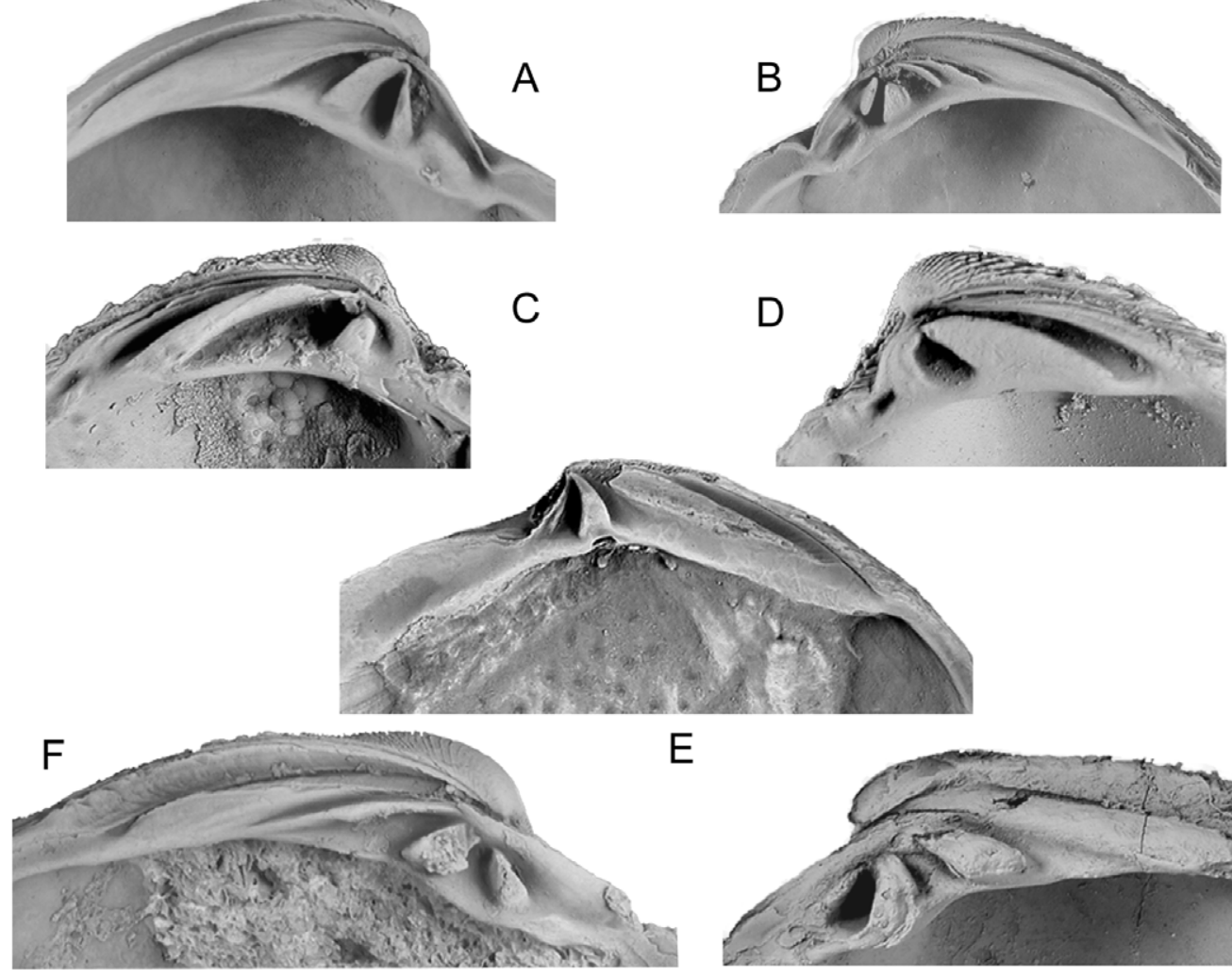

$E$

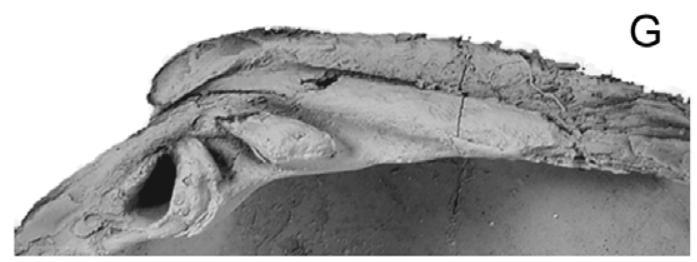

FIGURE 3 A, B, Dosinia (Kereia) numerosissima, sp. nov.: A, WAM 97.6a ( 2 2.7) holotype; B, WAM 97.6b (x 2.7) paratype; C, D, Venericardia capricornia sp. nov.: C, WAM 79.2857a (x 3.6) holotype; D, WAM 79.2857b (x 3.6) paratype; E, Miltha sp.: E, NMV P314122 (x 2.3); F, G, Periglypta weegeeree, sp. nov.: F, WAM 79.2860 b (x 1.8) holotype; G, WAM 79.2889 (x 1.8) paratype.

\section{REMARKS}

This is the first record for the genus in the Tertiary of Australia, though species are not uncommon in the living fauna of northern Australia. Records of fossil species are not common, so the stratigraphic distribution of the genus is poorly known. Periglypta miocenica (Michelotti, 1847) recorded from the Early to Middle Miocene of Europe and North Africa (Freneix et al. 1987 and references therein) may be the oldest occurrence for the genus hitherto. The present species is slightly more elongate and less subquadrate in comparison with the extant Periglypta puerpera (Linnaeus, 1771) from tropical waters in northern Australia.

A related and superficially similar genus, Proxichione Iredale, 1929, occurs in the Tertiary of southern Australia from the Late Oligocene to Recent (Darragh 2010). Species of Proxichione have a large, angular, pallial sinus and lack the prominent groove present on the escutcheon of species of Periglypta.

The species name is derived from an expression of the Yamatji (indigenous) language of the district of origin, which may be translated as 'weegeeree' or 'long time ago'.

\section{OCCURRENCE}

Merlinleigh Sandstone. Late Eocene.

\section{Subgenus Kereia Marwick, 1927}

\section{Dosinia (Kereia) numerosissima sp. nov.}

Figures 2E, G-I, 3A, B

\section{MATERIAL EXAMINED}

\section{Holotype}

Australia: Western Australia: WAM 97.6a, LV, from Kennedy Range, W.A. Eroded lower slope of mesa 1.6 $\mathrm{km}$ ESE of site of abandoned Merlinleigh homestead (type section of Merlinleigh Sandstone). Mount Sandiman LU 176087. Collected K. Ayyasami and G.W. Kendrick, 8.ix.1996.

\section{Paratypes}

WAM 97.6 b-1, 5LVs, 6RVs; P315513 LV, P31554 RV. From the type locality.

\section{Other material}

WAM 69.285 (2), 70.1670 (2), 70.1671 (see Remarks), 70.1687 (5), 79.2861 (4 + fragments), 97.7 (1), 97.11 (1). NMV P314114 (27), P314132 (17), P314307 (9), P314134 (26), P314295 (5), P314295 (5), P314290 (1). Total of 121 single valves.

\section{DESCRIPTION}

Up to median size for genus and subgenus, 


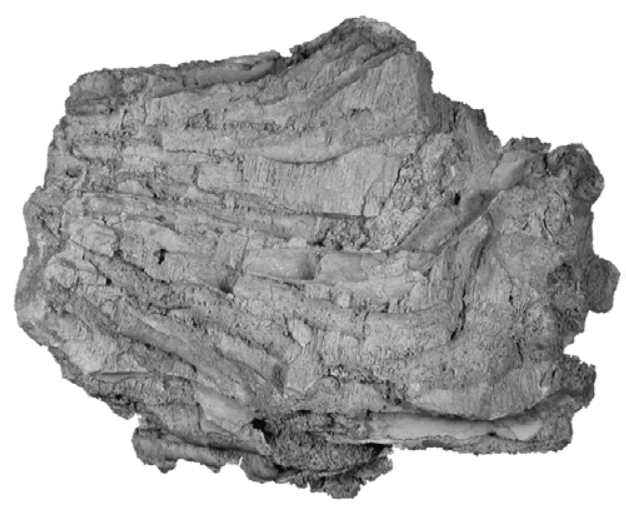

A

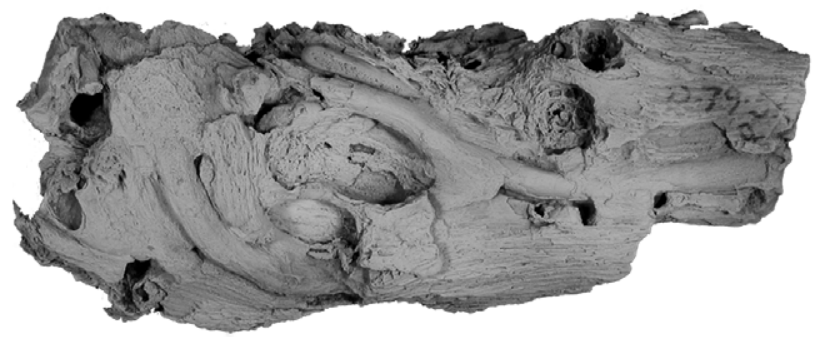

B
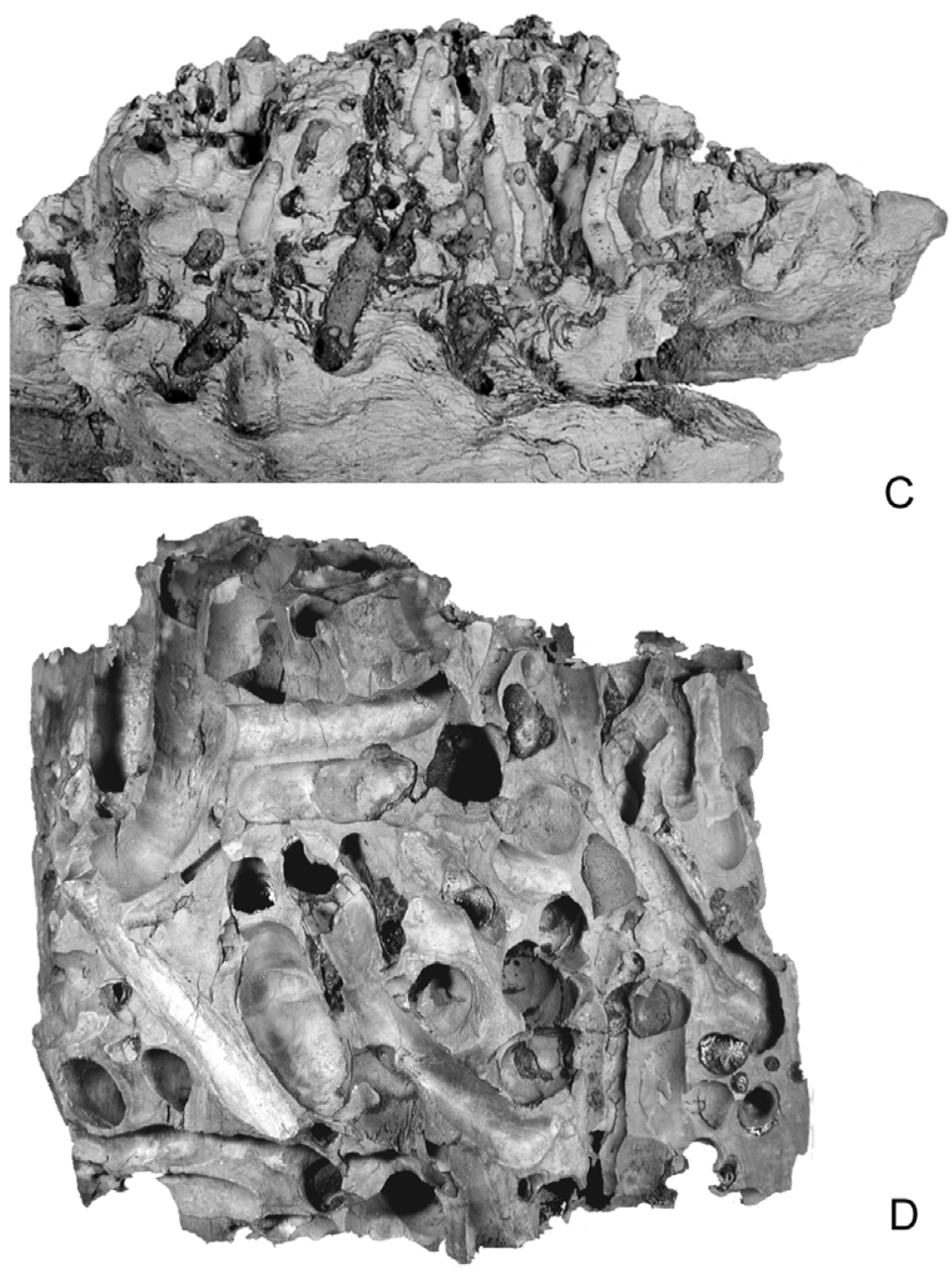

C

FIGURE 4 A, B, C, D, Teredinid genus and species undetermined: A, WAM P79.51b ( $x$ 0.9); B, WAM P79.51a (x 0.8); C, WAM P69.6c (x 1.3); D, NMV P315054 (x 0.6). 
subcircular, about as high as long, with pronounced, somewhat inflated (with growth), prosogyrous umbones and incurved beaks; lunule small, recessed; escutcheon wide, occupying most of dorsal margin. Sculpture of numerous well developed, thin, commarginal lamellae, increasing in height with growth. Hinge plate short, robust, ligament sunken, occupying most of hinge plate. Hinge of LV with short A11, narrow 2a, robust $2 b$ and extended, narrow $4 \mathrm{~b}$; RV with short $\mathrm{A} 1$, short narrow $3 a$, robust 1 and bifid $3 b$. Pallial sinus small, often obscured by sediment. Internal margin smooth.

\section{DIMENSIONS}

$\begin{array}{llll} & \text { Length } & \text { Height } & \text { Inflation } \\ \text { WAM 97.6a LV, holotype } & 33.3 & 32.9 & 10.6 \\ \text { WAM 97.6d RV, paratype } & 30.2 & 29.4 & 9.4 \\ \text { WAM 97.6f RV, paratype } & 32.9 & 32.6 & 9.6 \\ \text { WAM 97.6g LV, paratype } & 28.5 & 28.2 & 9.3 \\ \text { WAM 97.6k RV, paratype } & 35.5 & 35.7 & 11.2 \\ \text { NMV P315513 LV, paratype } & 31.3 & 29.3 & 9.0 \\ \text { NMV P315514 RV, paratype } & 34.5 & 34.2 & 10.5\end{array}$

\section{REMARKS}

The genus and subgenus are known from most of the southern Australian Tertiary strata, beginning with Dosinia (Kereia) imparistriata Tate, 1887 from the Late Eocene of South Australia (Tate 1887: 162, plate 14, figure 11). The sculpture of Tate's species features irregularly spaced, incised lines, not the regularly spaced lamellae of the Merlinleigh species, and the two taxa appear to be specifically distinct. Compared with $D$. (K.) densilineata Pritchard, 1896 from the Late Oligocene - Early Miocene of Victoria and Tasmania, Dosinia (Kereia) numerosissima sp. nov. is higher than long and less prosogyrous; the hinge is higher and more triangular and the sculpture, though similar, is a little coarser. The hinge of the Merlinleigh species is very similar to that of $D$. (K.) johnstoni Tate, 1887 from the Late Miocene-Early Pliocene of Victoria but the former has a coarser sculpture and more robust shell.

No congener of the present species is as yet known from the Middle/Late Eocene of the Bremer and Eucla Basins.

The entire sample of the present species comprises single valves, attesting to substantial post-mortem reworking of what was very probably an infaunal sediment dweller. A single exception to this circumstance is revealed by specimen WAM 70.1671, from the type section of the formation, comprising part of the conch of an Aturia measuring about $12 \times 6 \times 4 \mathrm{~cm}$, the sedimentary infilling of which contains abundant, juvenile, paired valves of this venerid species, all evidently representing a single generational cohort. A randomly chosen specimen from these juveniles measured $4.8 \times 4.6 \times 2.2 \mathrm{~mm}$.

The study material shows very limited evidence of predation: WAM 97.7, a fragmentary LV, shows a bevelled naticiform borehole on the umbo. Paratype 97.6b shows a small unsuccessful non-naticiform borehole, likewise located on the umbo.
The specific name refers to be abundance of the species in the study material.

\section{OCCURRENCE}

Merlinleigh Sandstone. Late Eocene.

Family Teredinidae Rafinesque, 1815

\section{Teredinid, genus and species undetermined}

Figures 4A-D

\section{MATERIAL EXAMINED}

Australia: Western Australia: Kennedy Range. WAM G10023 (2 specimens), P.69.6 (2), 70.1677 (1), P79.51 (2), P.97.6 (1); NMV P315054 (2). Total of 10 pieces of fossil wood with probable teredine tube infillings.

\section{DESCRIPTION}

See Remarks.

\section{REMARKS}

Fossil wood and diverse other remains of terrestrial vegetation (McNamara and Scott 1983) occur not infrequently in weathered residues from the Merlinleigh Sandstone, on and below erosion slopes of the Kennedy Range. Occasional specimens of such wood feature boreholes of teredine form, sometimes in abundance, subcircular in cross-section and infilled with silica and with borehole diameters ranging from about 1 to $13 \mathrm{~mm}$. The smaller tubes (c. $2 \mathrm{~mm}$ ) usually retain longitudinal septa but, in the study material, appear to lack other diagnostic features. Thus the holes and their siliceous infilling cannot be assigned to any taxon beyond the familial level.

\section{DISTRIBUTION}

Merlinleigh Sandstone. Late Eocene.

Class Gastropoda Cuvier, 1797

Family Fissurellidae Fleming, 1822

Genus Tugali Gray in Dieffenbach, 1843

Tugali? sp.

Figures 5G-I

\section{MATERIAL EXAMINED}

Australia: Western Australia: Kennedy Range. WAM 70.1689 (1 specimen); NMV P314118 (1), P314125 $(2+$ fragment). Total of four shells and fragment.

\section{DESCRIPTION}

Shell patelliform, oval, longer than wide; apex moderately raised, cap-like, at one-third of length from posterior margin; sculpture of 57-65 strong radial costae, about as wide as interspaces and crossed by 
irregular growth ridges; margin smooth. Muscle scar usually conspicuous, horse-shoe shaped and opening anteriorly.

\section{DIMENSIONS}

$\begin{array}{lllll} & \text { Length } & \text { Width } & \text { Height } & \text { Ribs } \\ \text { WAM 70.1689 } & 31.9 & 23.0 & 10.8 & 57 \\ \text { NMV P314125 } & 30.4 & 25.2 & 11.1 & 45 \\ \text { NMV P314118 } & 34.1 & 23.5 & \begin{array}{l}\text { (obscured } \\ \text { by matrix) }\end{array} & \text { c. 55 }\end{array}$

\section{REMARKS}

The apical areas and margins of all specimens to hand are either abraded or concealed by sediment so that the description must remain incomplete. No specimen shows an anterior notch, as has been noted for Tugali cicatricosa A. Adams recorded by Ludbrook (1956: 9-10) from the Middle Miocene Dry Creek Sands and Recent, Port Lincoln, South Australia. A high rib count and a greater width relative to length distinguish the present species from congeners cited by Ludbrook (1956) from the St Vincent Basin.

The shells are not unlike those of Clypidina but no internal groove has been observed. Subject to reevaluation based upon better preserved material, this would appear to be the earliest record for Tugali in the Australasian Region. In New Zealand, the genus is recorded first in the Waitakian (Early Miocene) (Beu and Maxwell 1990).

Small patelliform gastropods from the Albany district (Pallinup Formation) and Quagering Beds of the Northcliffe area attributed respectively to Cellana and Nacella (?) jutsoni (Chapman and Crespin, 1934) (Darragh and Kendrick 2000: 30, figure 4 L, N) are not unlike the present species though possibly with fewer ribs. Clarification of their relationship requires access to further, better preserved material.

\section{OCCURRENCE}

Merlinleigh Sandstone. Late Eocene.

\section{Family Turbinidae Rafinesque, 1815}

Genus Turbo Linnaeus, 1758

Subgenus Euninella Cotton, 1939

\section{Turbo (Euninella) sp. cf. T. (E.) hamiltonensis Harris, 1897}

Figures $5 \mathrm{~A}-\mathrm{F}$, L

cf. Turbo hamiltonensis Harris, 1897: 274, plate 8, figures 3a-c.

\section{MATERIAL EXAMINED}

Australia: Western Australia: Kennedy Range. WAM 79.2862 (1 abraded specimen, NMV P314119 (1 broken specimen, 1 operculum), P314127 (1 broken operculum),
P314129 (2 columellar fragments). Total of two incomplete shells, one complete operculum and fragments.

\section{DESCRIPTION}

Shell robustly turbinate with about five convexlygradate whorls; aperture continuous, expanded over anomphalous columella, internally grooved. Sculpture of spire spirally lirate, the posterior lirae strongly beaded with some fine lirae against the anterior suture; last whorl with well developed beading on anterior lirae. Operculum spiral, oval, flat internally, smooth and convex externally.

\section{DIMENSIONS}

The aperture of WAM 79.2862 has a transverse diameter of c. $29 \mathrm{~mm}$ and a height of c. $24 \mathrm{~mm}$. The operculum of NMV P314119 measures 15.6 × 12.8 × $4.8 \mathrm{~mm}$.

\section{REMARKS}

The limited material to hand is poorly preserved and inadequate for specific determination but seems to agree reasonably well with Euninella Cotton (type species Turbo gruneri Philippi, 1846), considered by Williams (2007, table 1) to be a 'probably valid' subgenus of Turbo Linnaeus, 1758. Compared with specimens of $T$. (E.) hamiltonensis Harris, 1897 from the Balcombian Muddy Creek Formation of the Otway Basin, the Merlinleigh species differs in its more rounded whorls, best shown on WAM 79.2862, and by the traces of beading on the basal lirae.

Opercula and a fragmentary shell, comparable to the present material, have been recovered from the Pallinup Formation, Bremer Basin (Darragh and Kendrick 2000: 39 , 40, figures $5 \mathrm{~L}-\mathrm{M}, \mathrm{O}$ ). Clarification of the identity of this turbinid material awaits the collection of better preserved material.

In a cladistic comparison of turbinid generic lineages, Williams (2007, figure 4) suggests a Miocene origin for Euninella within her Tropical Clade 5 component, all derived from the genus Turbo. Subject to confirmation, these turbinid records from Western Australia may extend the stratigraphic range of Euninella back from Miocene to Late Eocene.

\section{OCCURRENCE}

Merlinleigh Sandstone. Pallinup Formation? Late Eocene.

\section{Family Turbinellidae Swainson, 1835}

Genus Vasum Röding, 1798

\section{Vasum sp.}

Figure 5M

\section{MATERIAL EXAMINED}

Australia: Western Australia: Kennedy Range. NMV P314300. One specimen (fragment). 

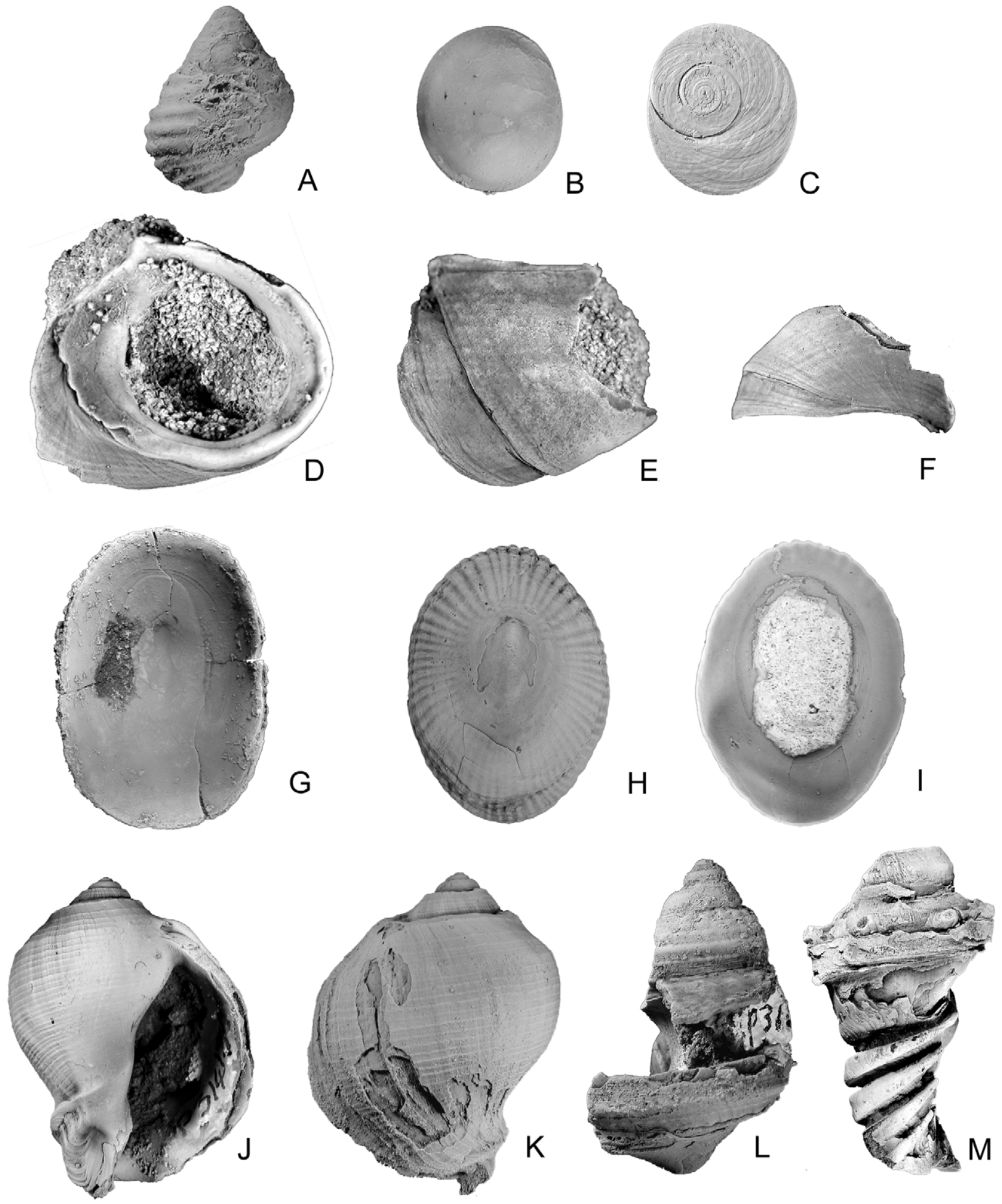

FIGURE 5 A, B, C, D, E, F, L, Turbo (Euninella) sp. cf. T. (E.) hamiltonenis Harris, 1897: A, NMV P314308 (x 4.5); B, C, NMV P314119 (x 1.8); D, E, F, WAM 79.2862 (x 1.2); L, NMV P314119 (x 1.9); G, H, I, Tugali? sp.: G, NMV P314118 (x 1.2); H, I, WAM 70.1689 (x 1.3); J, K, Zelandiella? sp.: J, K, NMV P314130 (x 1.9); M, Vasum sp.: M, NMV P314300 (x 0.9). 


\section{DESCRIPTION}

The specimen is part of a robust, biconic/fusiform shell with strongly spinose, spaced tubercles on the shoulder of the last whorl; a few thin spiral lirae can be seen below the suture. Four very strong columellar plaits are flattened at the top and extend to the upper turns of the columella.

\section{DIMENSIONS}

In its fragmentary condition, the specimen has a height of $55 \mathrm{~mm}$, width $31.5 \mathrm{~mm}$. When intact, it would have been the largest gastropod known to date from the Merlinleigh Sandstone.

\section{REMARKS}

Meaningful comparison with other taxa is not possible but what little remains of the specimen bears some resemblance in shape to Vasum humerosum Vaughan, 1896, Late Eocene, N. America (Vokes 1966: 4, plate 1, figure 1). This is the first record of the genus from the Eocene of Australia. It is a characteristic tropical genus, being represented in the fauna of northern Australian seas, but with a single relative - Vasum (Altivasum) flindersi (Verco) - living in southern and south western waters (Wilson 1994).

\section{OCCURRENCE}

Merlinleigh Sandstone. Late Eocene.

\section{Family Buccinidae Rafinesque, 1815 \\ Genus Zelandiella Finlay, 1926 \\ Zelandiella? sp.}

Figures 5J-K

\section{MATERIAL EXAMINED}

Australia: Western Australia: Kennedy Range. NMV P314130 (1). P314291 is a badly worn and decorticated specimen that might be of this genus.

\section{DESCRIPTION}

Shell of four spire whorls and one smooth, flattened protoconch whorl, the latter coiled with the axis of the shell. Spire whorls low, rapidly expanding, each succeeding whorl almost enveloping the previous; five lirae visible on the penultimate whorl and about 40 fine lirae on last whorl; whorls slightly flattened at posterior suture, latter becoming channelled with growth. Outer lip slightly sinuous posteriorly; columella twisted, short with deeply-notched anterior canal; siphonal fasciole well developed, bounded posteriorly by a prominent, sharp cord.

\section{DIMENSIONS}

$\begin{array}{llll} & \text { Height } & \text { Max. diameter } & \text { No. whorls } \\ \text { NMV P314130 } & 26.7 & 19.7 & 5\end{array}$

This species is assigned to the genus Zelandiella with some doubt, as it has little resemblance to most of the taxa included in that genus, which have high spires and coarse longitudinal costae or tubercles. An exception is Z. fatua Finlay, 1926 (Middle Miocene, New Zealand, Beu and Maxwell, 1990, Plate 30, figures c, d), which the Merlinleigh species does resemble in size, in its low spire, presence of spiral lirae and lack of costae. The Merlinleigh species differs from $Z$. fatua by having a much lower spire and much finer spiral lirae. If correctly assigned, the geographic range of the genus is extended to Australia and the stratigraphic range to Late Eocene. In New Zealand the genus ranges from Early Oligocene to Early Pliocene.

\section{OCCURRENCE}

Merlinleigh Sandstone. Late Eocene.

\section{Class Cephalopoda Cuvier, 1797}

Family Aturiidae Chapman, 1857

Genus Aturia Bronn, 1838

Aturia clarkei Teichert, 1944

Figures $6 \mathrm{~A}-\mathrm{J}$

Aturia cf. A. ziczac (Sowerby) Miller and Crespin, 1939: 80 , plate 14 , figure 1 ; text figures $1,2$.

Aturia clarkei Teichert, 1944: 79, plate 15, figures 1-4; plate 16, figures 1, 2: text figure 2; Glaessner, 1955: 354 , plate 34 , figure 2 , plate 35 , fig 3 , text figures $1-3$; Darragh and Kendrick, 2008: 220, figures 1.18, 1.19.

Aturia clarkei attenuata Teichert and Cotton, 1949: 255, plate 21.

Aturia sp. Haig and Mory, 2003, figures 3Q-R.

\section{MATERIAL EXAMINED}

Holotype

Australia: Western Australia: Kennedy Range. UWA 21406 from east side of Kennedy Range, on track, 1.3 miles $(2.1 \mathrm{~km})$ north of breakaway leading up to Merlinleigh Homestead.

\section{Paratypes}

UWA $21407 \mathrm{a}-\mathrm{e}$. From type locality (a-b not seen 16 September 2009).

\section{Other material}

(Merlinleigh Sandstone only). WAM G1008 (2 specimens), 64.35 (1 specimen), 66.1007-9 (3 specimens), 66.1011 (1 specimen), 69.277 (4 specimens) 69.287 (1 specimen) 69.288 (1 specimen associated with wood), 69.289 (4 specimens, 69.701-2 (2 specimens), 70.913 (5), 70.1378 (1 specimen), 70.1674 (1 specimen) 70.1676 ( 1 specimen), 70.1690-1 ( 2 specimens), 70.1693 (1 specimen) 78.639-42 (8 specimens), 79.286 (1 specimen), 79.2864-5 (2 specimens), 79.2894-6 (3 


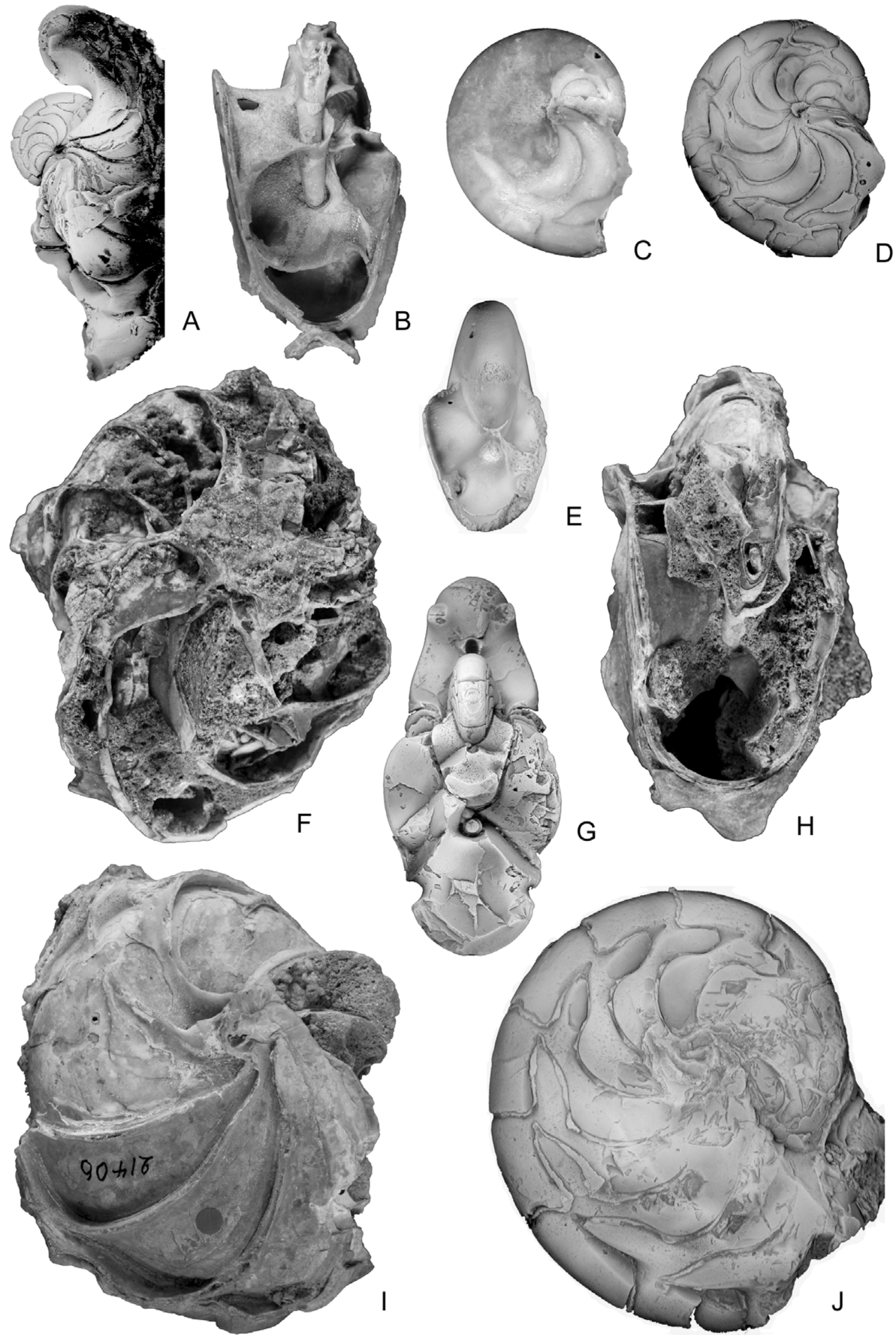

FIGURE 6 A, B, C, D, E, F, G, H, I, J, Aturia clarkei Teichert, 1944: A, G, WAM 64.35 (x 0.8); B, WAM 79.2866g (x 0.8); C, E, WAM 70.1691 (x 0.8); D, WAM 78.639a (x 0.8); F, H, I, UWA 21406 ( $x$ 0.8) holotype ; J, WAM 78.643 $(x 0.8)$. 
specimens), 79.2900 (1 specimen) 79.2902 (1 specimen), 83.2449 (3 specimens), 87.474 (1 specimen), 88.849 (1 specimen), 97.1 (1 specimen). NMV P314306 (4 specimens), (P314894 (1 specimen), P314895 (1), P314896 (2 specimens), P315053 (3 specimens).

\section{DESCRIPTION}

The study material, including the type series, is on the whole poorly preserved and fragmentary, revealing little more than a cursory indication of the salient features of the species. When intact, the shell would have attained a diameter of up to c. $300 \mathrm{~mm}$, being smooth, involute, compressed and broadly rounded across the venter; umbilicus closed; about 10-11 camerae per volution, frequently exposed by attrition of the outer shell layer. Suture almost flat across venter with a narrow, asymmetrical, pointed lateral lobe, a broadly rounded, asymmetrical lateral saddle and a wide, shallow umbilical lobe.

The holotype is a fragmentary internal replication, bordered by the siphuncle and devoid of any portion of the outer surface or aperture. The maximum measurable diameter of this specimen is $100 \mathrm{~mm}$, consistent with a diameter of c. $300 \mathrm{~mm}$ or more) when intact.

Of the paratype series UWA 21407 a-e, specimens a and $b$ were not seen on 16 September 2009; specimen $\mathrm{c}$ is noteworthy for the retention of part of the external shell surface near the aperture (right side), something of a rarity in the study material as a whole.

\section{DIMENSIONS}

$\begin{array}{lll} & \text { Max. diameter } & \text { Width } \\ \text { UWA 21406, holotype } & 100 & 42 \\ \text { WAM 70.1691 } & 44.0 & 23.5 \\ \text { WAM 78.639a } & 45.5 & 22.0 \\ \text { WAM 64.35 } & 72.0 & 31.5 \\ \text { WAM 78.643 } & 84.0 & 31.0 \\ \text { WAM 78.2886g } & - & 38.0\end{array}$

\section{REMARKS}

Aturia had a virtually cosmopolitan distribution in the Eocene. In explaining this, Chirat (2000) has argued that, because of their unique siphuncular morphology, the shells, after death, probably drifted for very long distances, so that the number of true bio-species compared with recorded taxa is probably quite small. Many 'species' appear to have been erected for reasons of geographical separation or dispersal and from minor morphological differences or based on few specimens, poorly preserved. We have noted at least 22 names that have been proposed for Eocene 'species' of Aturia (Kummel 1956) and have priority over A. clarkei and it seems highly probably that Teichert's name will prove to be a junior subjective synonym of one of these.

The earliest available names for Eocene species appear to be Aturia ziczac (J. Sowerby, 1812) and A. alabamensis (Morton, 1834). Judging from illustrations, A. clarkei appears to be very close in morphology to both of them but, without being able to compare good specimens, we are unable to state at present with any certainty whether the latter is a synonym of either of the former, if indeed the former represent one or two separate species or whether A. clarkei is a synonym of any of the other recorded taxa. In view of this uncertainty, we retain Teichert's name for the time being. As Chirat (2000) has pointed out, the genus is in need of revision, something we are not in a position to undertake at present.

In the Middle to Late Eocene of Western Australia, specimens of $A$. clarkei are not uncommon, usually as small or broken specimens or as siliceous internal casts. This fact, together with the character of the Merlinleigh Sandstone, is in accord with Chirat's (2000) comments that many occurrences (of Aturia) represent shoreline strandings - the shells having been transported by ocean currents over greater or lesser distances from their original habitats. All but a very few Merlinleigh specimens show substantial shell fragmentation, consistent with a high degree of predation prior to stranding and burial.

\section{OCCURRENCE}

Australia only. Otway Basin: Clifton Formation (reworked). St Vincent Basin: Tortachilla Limestone. Bremer Basin: Pallinup Formation. Southern Carnarvon Basin: Merlinleigh Sandstone (type); unnamed sandstone (Kalbarri). Middle-Late Eocene.

\section{ACKNOWLEDGEMENTS}

We gratefully acknowledge the assistance of Mrs Jenny Bevan of the E. de C. Clarke, School of Earth and Environmental Sciences, University of Western Australia, for providing access to the type specimens of Aturia clarkei and Mr Clay Bryce, Western Australian Museum, for photographs of those specimens. $\mathrm{Mr}$ Ross Chadwick, Western Australian Museum, kindly provided a Yamatji (indigenous) word list, the source of a species name appropriate to the Merlinleigh area, and Dr Alan Beu, Institute of Geological and Nuclear Sciences, New Zealand, provided useful information on possible generic assignments.

\section{REFERENCES}

Adams, H. and Adams, A. (1857). The genera of recent Mollusca, vol. 2. John van Vorst: London.

Beu, A.G. (2006). Marine Mollusca of oxygen isotope stages of the last 2 million years in New Zealand. Part 2. Biostratigraphically useful and new Pliocene to Recent bivalves. Journal of the Royal Society of New Zealand 36: $151-338$.

Beu, A.G. and Darragh, T.A. (2001). Revision of southern Australian Cenozoic fossil Pectinidae (Mollusca: Bivalvia). Proceedings of the Royal Society of Victoria 113: 1-205.

Beu, A.G. and Maxwell, P.A. (1990). Cenozoic Mollusca of New Zealand. New Zealand Geological Survey Paleontological Bulletin 58: 1-518.

Bronn, H.G. (1838). Lethaea Geognostica, oder, Abbildungen 
und Beschreibungen der fur die Gebirgs-Formationen bezeichnendsten Versteinerungen, vol. 2. E. Schweizerbart: Stuttgart.

Brunnschweiler, R.O. (1962). On echinoids in the Tertiary of Western Australia with a description of two new Eocene Fibulariidae. Journal of the Geological Society of Australia 8: $159-169$.

Chapman, E.J. (1857). On the occurrence of the genus Cryptoceras in Silurian rocks. Annals and Magazine of Natural History $2^{\text {nd }}$ Series, 20: 114-117.

Chapman, F. and Crespin, I. (1934). The palaeontology of the Plantagenet Beds of Western Australia. Journal of the Royal Society of Western Australia 20: 103-136.

Chapman, F. and Singleton, F.A. (1925). A revision of the Cainozoic species of Glycymeris in southern Australia. Proceedings of the Royal Society of Victoria 37: 18-60.

Chirat, R. (2000). The so-called 'cosmopolitan palaeobiogeographic distribution' of Tertiary Nautilida of the genus Aturia Bronn, 1838: the result of post-mortem transport by oceanic palaeocurrents. Palaeogeogeography, Palaeoclimatology, Palaeoecology 157: 59-77.

Cockbain, A.E. (1981). On the age of the Merlinleigh Sandstone, Carnarvon Basin. Annual Report of the Geological Survey of Western Australia for 1980: 44-46.

Condon, M.A. (1954). Progress report on the stratigraphy and structure of the Carnarvon Basin, Western Australia. Bureau of Mineral Resources Report 15.

Cotton, B.C. (1939). The Sir Joseph Banks Islands. Reports of the expedition of the McCoy Society for Field Investigation and Research. Part Two. 4. Mollusca, Part 2; General. Proceedings of the Royal Society of Victoria 51: 159-176.

Cuvier, G. (1797). Tableau élémentaire de l'histoire naturelle des animaux. Baillière: Paris.

d'Orbigny, A.D. (1850) Prodrome de paléontologie stratigraphique universelle des animaux mollusques \& rayonnés faisant suite au Cours élémentaire de paléontologie et de géologie stratigraphiques. V. Mason: Paris.

Da Costa, E.M. (1778). Historia naturalis Testaceorum Britanniae, or, the British Conchology. Millan, White, Elmsley and Robson: London.

Darragh, T.A. (1985). Molluscan biogeography and biostratigraphy of the Tertiary of southeastern Australia. Alcheringa 9: 83-116.

Darragh, T.A. (2010). A new species of the genus Proxichione (Bivalvia: Veneridae) from Western Australia with notes on Late Tertiary species. Records of the Western Australian Museum 25: 369-377.

Darragh, T.A. and Kendrick, G.W. (1980). Eocene bivalves from the Pallinup Siltstone near Walpole, Western Australia. Journal of the Royal Society of Western Australia 63: 5-20.

Darragh, T.A. and Kendrick, G.W. (2000). Eocene bivalves and gastropods from the Pallinup Siltstone, Western Australia, with new records from the Eocene and Oligocene of southeastern Australia. Proceedings of the Royal Society of Victoria 112: 17-58.

Darragh, T.A. and Kendrick, G.W. (2008). Silicified Eocene molluscs from the Lower Murchison district, southern Carnarvon Basin, Western Australia. Records of the Western Australian Museum 24: 217-246.

Finlay, H.J. (1926). New shells from New Zealand Tertiary beds; Part 2. Transactions of the New Zealand Institute 56: 227-258.

Fleming, J. (1822). The philosophy of zoology; or a general view of the structure, functions, and classifications of animals. A. Constable: Edinburgh.

Fleming, J. (1828). A history of British animals, exhibiting the descriptive characters and systematical arrangement of the genera and species of quadrupeds, birds, reptiles, fishes, mollusca, and radiata of the United Kingdom ... Bell \& Bradfute: Edinburgh.

Freneix, S., Saint Martin, J-P. and Moissette, P. (1987). Bivalves Hétérodontes du Messinien d'Oranie (Algérie occidentale). Bulletin du Muséum National d'Histoire Naturelle sér. 4, 9 C, 4: 415-453.

Glaessner, M.F. (1955). Pelagic fossils (Aturia, penguins, whales) from the Tertiary of South Australia. Records of the South Australian Museum 11: 353-372.

Glenister, B.F. and Glover, J.E. (1958). Teichertia in the Plantagenet Beds of Western Australia. Journal of the Royal Society of Western Australia 41: 84-87.

Gray, J.E. (1826). On a recent species of the genus Hinnita of De France, and some observations on the shells of the Monomyaires of Lamarck. Annals of Philosophy 28: 103-106.

Gray, J.E. (1843). Fauna of New Zealand. Materials towards a fauna of New Zealand, Auckland Island, and Chatham Islands (pp. 177-296). In: E. Dieffenbach (ed.), Travels in New Zealand ... vol. 2. J. Murray: London.

Haig, D.W. and Mory, A.J. (2003). New record of siliceous, marine, later Eocene from Kalbarri, Western Australia. Journal of the Royal Society of Western Australia 86: 107-113.

Harris, G.F. (1897). Catalogue of Tertiary Mollusca in the Department of Geology, British Museum (Natural History). Part 1. The Australasian Tertiary Mollusca. 177-296. London.

Johnstone, M.H., Lowry, D.C. and Quilty, P.G. (1973). The geology of southwestern Australia - a review. Journal of the Royal Society of Western Australia 56: 5-15.

Jukes-Browne, A.J. (1914). A synopsis of the family Veneridae. Proceedings of the Malacological Society of London 11: 58-94.

Kendrick, G.W., Wyrwoll, K.-H., and Szabo, B.J. (1991). Pliocene-Pleistocene coastal events and history along the western margin of Australia. Quaternary Science Reviews 10: 419-439.

Kummel, B. (1956). Post-Triassic nautiloid genera. Bulletin of the Museum of Comparative Zoology 114: 324-494.

Lamarck, J.B. de (1801). Système des animaux sans vertèbres. Deterville: Paris.

Lamarck, J.B. de (1809). Philosophie zoologique, ou Exposition des considérations relatives à l'histoire naturelle des animaux.. Dentu: Paris.

Linnaeus, C. (1758). Systema naturae per regna tria naturae, secundum classes, ordines, genera, species, cum characteribus, differentiis, synonymis, locis. L. Salvius: Holmiae.

Lowry D.C. (1970). Geology of the Western Australian part of the Eucla Basin. Geological Survey of Western Australia Bulletin 122: 1-201.

Ludbrook, N.H. (1955). The molluscan fauna of the Pliocene strata underlying the Adelaide Plains. Part II - Pelecypoda. Transactions of the Royal Society of South Australia 78: $18-87$.

Ludbrook, N.H. (1956). The molluscan fauna of the Pliocene strata underlying the Adelaide Plains. Part III. Scaphopoda, Polyplacophora, Gastropoda (Haliotidae to Tornidae). 
Transactions of the Royal Society of South Australia 79: $1-36$.

Ludbrook, N.H. (1965). Revision of the Tate molluscan types Part 3. Limposidae, Glycymeridae, Arcidae, Cucullaeidae. Transactions of the Royal Society of South Australia 89: 81-114.

Ludbrook, N.H. (1967). Tertiary molluscan types from Table Cape in the Tasmanian Museum, Hobart. Papers and Proceedings of the Royal Society of Tasmania 101: 65-69.

Ludbrook, N.H. (1969). The genus Miltha (Mollusca: Bivalvia) in the Australian Cainozoic. Transactions of the Royal Society of South Australia 93: 55-63.

Marwick, J. (1927). The Veneridae of New Zealand. Transactions of the New Zealand Institute. 57: 567-635.

Miller, A.K. and Crespin, I. (1939). An Aturia from the Northwest Division of Western Australia. Journal of Palaeontology 13: 79-81.

McCoy, F. (1876). Prodromus of the palaeontology of Victoria. Decade 4: 1-32, plates 31-40.

McLoughlin, S. and Hill, R.S (1996). The succession of Western Australian Phaneroziic terrestrial floras (pp. 61-80). In: S.D. Hopper, Chappill, J.A., Harvey, M.S. and George, A.S. (eds), Gondwanan heritage past, present and future of the Western Australian biota. Surrey Beatty \& Sons, Chipping Norton, Australia.

McLoughlin, S. and McNamara, K. (2001). Ancient floras of Western Australia. Western Australian Museum: Perth.

McNamara, K.J. and Scott, J.K. (1983). A new species of Banksia (Proteaceae) from the Eocene Merlinleigh Sandstone of the Kennedy Range, Western Australia. Alcheringa 7: 185-193.

Newton, R.B. (1891). Systematic list of the Frederick E. Edwards collection of British Oligocene and Eocene mollusca in the British Museum (Natural History). British Museum (Natural History): London.

Newton, R.B. (1916). On the conchological features of the Lenham sandstones of Kent and their stratigraphical importance. Journal of Conchology 15: 65-84, 112-118.

Playford, P.E. et al. (1975). Phanerozoic. In: The geology of Western Australia. Geological Survey of Western Australia Memoir 2: 223-433.

Pulley, J.M. (1959). Corals from the Merlinleigh Sandstone of the Carnarvon Basin, Western Australia. Bureau of Mineral Resources, Geology and Geophysics Report 38: 113-117.

Rafinesque, C.S. (1815). Analyse de la Nature ou Tableau de l'Univers et des Corps Organises. Published by author: Palermo.
Röding, P.F. (1798). Museum Boltenianum sive Catalogus cimeliorum e tribus regnis naturae quae olim collegerat Joa. Fried. Bolten, : pars secunda continens conchylia sive testacea univalvia, bivalvia \& multivalvia. J.C. Trap: Hamburg.

Scopoli, J. A. (1777). Introductio ad historiam naturalem, sistens genera lapidum, plantarum et animalium hactenus detecta, caracteribus essentialibus donata, in tribus divisa, subinde ad leges naturae. Wolfgang Gerle: Prague.

Singleton, F.A. (1932). Studies in Australian Tertiary Mollusca. Part 1. Proceedings of the Royal Society of Victoria 44: 289-308.

Stewart, R.B. (1930). Gabb's California Cretaceous and Tertiary type Lamellibranchs. The Academy of Natural Sciences of Philadelphia Special Publication 3: 1-314.

Swainson, W. (1835). The elements of modern conchology; briefly and plainly stated for the use of students and travellers. Baldwin and Cradock: London.

Swainson, W. (1840) A treatise on malacology; or the natural classification of shells and shellfish. Lardner's Cabinet Cyclopedia. Longman, Orme, Brown, Green \& Longmans: London.

Tate, R. (1886). The lamellibranchs of the Older Tertiary of Australia. (Part 1). Transactions and Proceedings of the Royal Society of South Australia 8: 96-158.

Tate, R. (1887). The lamellibranchs of the Older Tertiary of Australia. Part II. Transactions of the Royal Society of South Australia 9: 142-189.

Tate, R. (1899). A revision of the Older Tertiary Mollusca of Australia. Part 1. Transactions of the Royal Society of South Australia 23: 249-277.

Teichert, C. (1944). The genus Aturia in the Tertiary of Australia. Journal of Paleontology 18: 73-82.

Tenison Woods, J.E. (1877). Notes on the fossils referred to in the foregoing paper. Proceedings of the Royal Society of Tasmania for 1876: 91-116.

Vokes, E.H. (1966). The genus Vasum (Mollusca: Gastropoda) in the New World. Tulane Studies in Geology 5: 1-36.

Williams, S.T. (2007). Origins and diversification of IndoWest Pacific marine fauna: evolutionary history and biogeography of turban shells (Gastropoda, Turbinidae). Biological Journal of the Linnean Society 92: 573-592.

Wilson, B.R. (1994). Australian marine shells. Prosobranch gastropods Part 2 (Neogastropods). Odyssey: Kallaroo, Australia.

MANUSCRIPT RECEIVED 15 OCTOBER 2009; ACCEPTED 2 FEBRUARY 2010. 